\title{
Risk Consulting in Public Administration: Evidences of Insurance Brokers in the Emilia-Romagna Municipalities
}

\author{
Vincenzo Riso, PhD Candidate \\ Department of Economics and Business Sciences, University of Parma, Italy \\ Monia Castellini, PhD \\ Department of Economics and Management, University of Ferrara, Italy
}

\begin{abstract}
Over the past years, risk management has been embedded in all public administration and scholars have asserted the need to improve the research about it. This paper aims to understand if an insurance broker has a role in the public administration risk management system, analysing the relationship between the operational risk management activities and control systems in the public administration and the evolution of the insurance broker as a risk consultant. Finally, through a content analysis, this study presents an observation about 331 municipalities from the Emilia-Romagna to understand how many municipalities can have an insurance broker as a partner.
\end{abstract}

Keywords: Public Administration, Management Control System, Insurance broker, Risk Consultant, Risk Management

\section{Introduction}

Over the past decades, public administration's management and internal control has garnered much attention, emphasising on the need to strengthen organisations that operate in over-regulated situations with increasingly scarce resources (Rana et al, 2019; Soin \& Collier, 2013). In an environmental context, widely characterised by frequent changes in market rules, legal provisions and technologic innovations, public administration plays a central role at every level of social life (Khan, 2017). Furthermore, to achieve its social and economic objectives every public administration implements a management control system and an internal control system

\footnotetext{
${ }^{1}$ Although the article is the result of the joint work of the authors, it is possible to attribute the paragraphs 1 and 2 to Monia Castellini and the paragraphs 3, 4 and 5 to Vincenzo Riso.

We thank for the suggestions received in the VII Workshop of Management Control Review placed in Cagliari, 25 May 2018
} 
(Verbeeten \& Speklé, 2015). Every country, in line with its government and political addresses, may identify guidelines to implement these systems (OECD, 1996). In this scenario, risk analysis represents a vital component of the public management control system (Raczkowski, 2017). Risk management culture is not significantly widespread in public organisations. Keban (2017), in his case study, stressed on this phenomenon. Moreover, other authors explain how risk management was embedded in the public administration but was not investigated similarly (Hinna et al., 2018).

The evolution of the governance system in public administration from the 'Old Public Administration' to 'New Public Service' and 'New Public Management' - means rethinking its organisational structure (Maran and Bracci, 2018, Robinson, 2015, Guthrie, 2005; Hood, 2001). This evolution generally moves from a bureaucratic organisation with a top-down authority to a collaborative structure with shared leadership (Denhardt \& Denhardt, 2000). Thus, shared leadership facilitates popular collaborations with advisors and professionals in the pursuit of objectives (Robinson, 2015).

The performance management approach was introduced to public administration as a logical, business-oriented performance management (Arnaboldi et al, 2015) approach, focusing on the organisation's performance and accountability. Indeed, Bracci et al. (2013) explain that, "performance management systems are at the heart of public sector reforms in Italy, which reflect a shift towards a more effective and efficient public sector management". There is a strict relationship between performance management and risk management activities (Gordon et al, 2009) and many studies analyse how risk management practices improve firms' performance (Barton et al., 2002; Lam, 2003; Stulz, 2003; COSO, 2004; Hoyt \& Liebenberg, 2009).

A recent survey (CINEAS, 2018) shows how enterprises implement risk management logic within their organisations to improve their performance in the Italian private sector. However, in the public sector, Petak (1985) explained that the particularity of risk management implies that not all public administrations have the skills and instruments to implement a control system to evaluate risk management and operational risks. This phenomenon is likely present in all public organisations but its relevance differs for small and medium organisations that may have inadequate resources, like time or skills (Cardon \& Stevens, 2004), to implement a risk management system or manage operational risks. To remedy this, public administration engages external experts and "it is important to note that current decision-making approaches tend to put a great deal of power in the hand of technical experts and professional administrator who are not directly accountable to the public" (Petak, 1985).

Public local administrations, like every other organisation, are subject to many risks that could impede the achievement of its objectives. These risks 
have various implications and occur at various levels of the organisations (Nilsen \& Olsen, 2005; Capaldo et al., 2018). Therefore, in line with Kaplan and Garrick's 1981 statement that, "we are not able in life to avoid risk but only to choose between risks", this work considers the operational risk, as reported and explained in the INTOSAI GOV 9130 guidelines, to implement a risk management logics in the public sector. Within this context, operational risk management should be defined with the objective to "[execute] orderly, ethical, economical, efficient and effective operations; and safeguarding resources against loss, misuse and damage" (INTOSAI Gov 9130, 2004, p.10).

The L.D. $267 / 2000$ provides a set of rules about their role and functions of the Italian local public entities from this study.

Especially, Art. 196 sets forth that every public local entity should (or must) implement a management control system to ensure:

1) the achievement of the planned objective,

2) economical management of the public resource,

3) good performance of the public administration.

The risk analysis and risk management operations include planned activities to assure an effective response to the risks.

The aim of this work is to understand two main issues:

1) The legislative inattention towards the management of municipalities' operational risks;

2) Whether insurance brokers could play a role in the public control system.

The first part tries to explain the control system of municipalities. Additionally, whether the insurance broker could be a strategic partner as a risk consultant in local administrations is discussed.

In the second part, the observation method is used to detect the number of municipalities collaborating with insurance brokers as a partner in the region of Emilia-Romagna which has 331 municipalities.

\subsection{An overview on risk management in public administration}

This study considers two main themes and strands of scientific literature. First, the function of internal control in public administration and second, the evolution of the insurance broker's professional purposes.

Considering this aim, the literature review conducted reveals that the involvement of the insurance broker in public administration is not well developed in scientific rather than practical works. The prevailing theme of the relevant literature on the broker in the insurance market is the difference between agents (exclusive or independent). Other authors, instead, focus on market failures and the implications of insurers' distributions strategies. This research focuses on the quality of insurance broker services not only as 
intermediaries but also as consultants or advisors. Table 1 provides an overview of the principal theories and authors analysed.

The evolution of new public management has introduced the 'way to do' things to the Public Administration, which were historically used in the private sector (Hood, 1995; Robinson, 2015)

In keeping with this trend, in the 1990s, Italy implemented a series of reforms to introduce the management control system (broadly, 'control' instruments) within public organisations (Ongaro \& Vallotti, 2008).

Indeed, the Italian Department for the Public Function (2001) provided the first Operative Manual for Management Control addressed to all public administration to introduce the management control system and share best practices.

Passage from the 'old' to 'new' system in the reform process addressed performance management (Maran \& Bracci, 2018; Bracci et al, 2017; Robinson, 2015; Guthrie, 2005; Hood, 2000; Hood, 2005) to achieve a more effective, efficient and customer/citizen-oriented performance (Larbi, 1999). Literature Background on Three Principals' Theme (New Public Management, Management Control and Risk Management, Insurance Broker)

\begin{tabular}{|c|c|c|c|}
\hline Theories and Issues & Year (from-to) & Principal Authors & Considerations \\
\hline $\begin{array}{l}\text { New Public Management } \\
\text { and its evolutions }\end{array}$ & $1995-2018$ & $\begin{array}{l}\text { Bracci, Denhardt, } \\
\text { Guthrie, Hood, Kanh, }\end{array}$ & $\begin{array}{l}\text { The evolution of } \\
\text { Public }\end{array}$ \\
\hline & & Kickert, Larbi, & Administration \\
\hline & & $\begin{array}{l}\text { Maran, } \\
\text { Robinson }\end{array}$ & Governance \\
\hline $\begin{array}{l}\text { Management Control and } \\
\text { Risk Management }\end{array}$ & $1985-2018$ & $\begin{array}{l}\text { Mussari, Hatvanti, } \\
\text { Keban, Petak, Peta, } \\
\text { Raczkowski, Ruffini, } \\
\text { INTOSAI, European } \\
\text { Commission }\end{array}$ & $\begin{array}{l}\text { The role of Internal } \\
\text { Control System and } \\
\text { risk management } \\
\text { functions }\end{array}$ \\
\hline $\begin{array}{l}\text { Insurance Broker as Risk } \\
\text { Consultant }\end{array}$ & $1995-2016$ & $\begin{array}{l}\text { AIBA, Cummins, } \\
\text { Doherty, Maas, Page, } \\
\text { Rosenthal, Eckardt } \\
\text { and Räthke-Döppner, } \\
\text { Dumm, Focht et al, } \\
\text { Schmit and Roth }\end{array}$ & $\begin{array}{l}\text { The evolution of } \\
\text { insurance broker } \\
\text { services }\end{array}$ \\
\hline
\end{tabular}

According to Mussari (2001), the public local administration's use of instruments like 'management control' and 'performance management', typically used in the private sector, do not imply abandoning equality and courtesy in serving the public.

In the scientific literature, some studies on management and organisation theory affirm that their theories are equally applicable to the public and private sectors (Kickert, 2001). 
In this context, the Italian public administration provided a series of reforms (i.e. before L.D. 286/1999, then L.D. 156/2009) in the 2000s to endow public organisations with management instruments and to achieve the objectives of management control in an orderly manner (Ongaro \& Vallotti, 2008).

According to Ruffini (2010), it is possible to offer a joint view about the control system provided by the reforms processes in the Matrix of the Public Controls to the public administration.

From an internal and external perspective, the risk management function transverses the entire system.

Indeed, the provision to ensure goals and knowledge thereof were achieved as reported in the L.D. 156/2009 and in others provisions is in line with the risk management aim defined by Hatvani et al (2015). The authors, in fact, explained that the entire risk management process increases awareness about the organisational goals and relevant risks to their objectives.

Hinna et al. (2018) explain how "Though Risk Management (RM) entered the public sector, the way RM is introduced within organisations is not empirically explored".

The goal of risk management is not reducing the number of risks or avoiding them but minimising the possible effects of risks through a high level of awareness (Hornai, 2001, Keban, 2017).

Indeed, the public value derived from a correct risk management introduction in the public management control system implies that, "value creation and value preservation do not have as much direct relevance as in the private sector...As such it is possible to substitute service creation and preservation for value creation and preservation for the definition to be fully applicable to public sector entities" (INTOSAI Gov 9130, 2004).

According to INTOSAI's concept of value, the public world's adoption of risk management logic could benefit a community interested in appropriately managing public resources.

There are more operating procedures, standards and guidelines for risk management in the private sector, such as the COSO ERM, the HM Treasury Orange Book, INTOSAI GOV 9310 Guidelines, the Risk Management standards by the Institute of Risk Management (2002), the Australian and New Zealand Risk Management Standards (2004) (Hatvanti et al, 2015). However, the lack of a specific legislative provision about operational risk management practises in public administration lead to it being carried out solely based on the public organisation's sensibilities.

Particularly within the public control system, there is an unsatisfactory level of permeation in the Italian public organisations (Reginato et al, 2012) due to the lack of legislative framework and policymakers' scepticism regarding the utility and benefits of an efficient control system (Peta, 2016). 
In this scenario, the management control system is the cornerstone of risk management culture. The management of the public local administration would ideally go beyond the typical boundaries of the management control system and consider the best operational risks management practices to achieve the organisation's objectives (Kapuscinska \& Matejun, 2014, p. 132). About the lack of risk management logic in public administration, Peta (2016) affirms, "If on one hand, the Italian legislative framework contemplates in abstract formal instruments necessary to ensure the function of the internal control system (like the four types of control, the empowerment of the directors, supporting the management control with the analytical accounting), on the other, the action of this last don't appear informed to the risk logic" (p. 24).

The INTOSAI (2004) provides specific guidelines for the implementation of entity risk management in the public sector, explaining that the aim of risk management is to enable the management to effectively deal with uncertainty and evaluate risks and opportunities, enhancing the capacity to build and create value and deliver services more efficiently (INTOSAI Gov 9130, 2004).

Furthermore, the European Commission developed a reference model for the public sector called Public Internal Financial Control (PFIC) to provide a structured and operational model to assist national governments and public administrations in reengineering the internal control environment in line with international standards (like INTOSAI guidelines) and EU best practises (EC, 2006).

However, Reginato et al. (2012), by comparing PFIC components of internal control and Italian regulation in the public sector, illustrate the absence of a close relationship between both and that risk assessment process (a first step of a risk management) is not contemplated in the Italian regulation. Indeed, operational risk management activities do not appear in the Italian public organisation system as an explicit duty within the control system but rather as a best practice (Riso \& Castellini, 2019).

Furthermore, there are no specific norms for managing and controlling operational and relative risk management activities. Conversely, there are, for example, legislative provisions about corruption risk (i.e. L. 190/2012) and the risk related to companies' and entities' administrative liabilities (i.e. L.D. 231/2001).

\subsection{Insurance broker: intermediary or advisor?}

The insurance broker is a professional figure defined in the Italian legislative system by the L.D. 209/2005, called Code of Private Insurance. 
Article 106 explains how the insurance broker conducts insurance and reinsurance intermediation, presenting and proposing insurance products and advising about the ultimate outcomes.

The provision presents two principal activities: intermediation (of contracts) and consultation.

In the traditional view, according to Cummins and Doherty (2005), the insurance broker is: an intermediary between the buyer and insurer [who] plays the role of 'market maker'... [and has the role] to scan the market, match buyers with insurers who have the skill, capacity, risk appetite, and financial strength to underwrite the risk [and to] help their client [to] select from competing offers.

However, this professional role changes their original function of being an intermediary between the insurer and the client by also becoming a Risk Consultant (Rosenthal, 1995) which focuses on the strong part of their services: advising (Maas, 2006).

Few works discuss the know-how of insurance brokers as risk managers and consultants. Rosenthal (1995) first identified consultative services as the future of this profession. More than 20 years later, through a functional approach, Maas (2006) presented the ways in which an insurance broker creates value and showed that the principal service cited by clients was the broker's advice.

These aspects and themes also find that practitioners share this interest. PwC research conducted by Frank et al. (2014) shows that the services provided by insurance brokers change over time as they innovate business models in line with market demands for advisory services.

Insurance brokers contribute to transparency in the insurance market, but their dual role in the market (intermediation and consultation) implies that, "the insurance intermediary market itself is characterised by information gaps since consumers act under asymmetric information about the quality of the information and advisory services provided by the intermediaries" (Eckardt \& Räthke-Döppner, 2010, p. 667).

Some factors, like innovations in information and communication technology, the birth of the knowledge economy and others, have and still do change this segment of the insurance industry (Rajola et al, 2016).

As reported earlier, these challenges in the market have interested some practitioners and consultants, highlighting the idea that although the professional role of the insurance broker is old, it has evolved over time, adapting to market needs.

In this environment, the academic's role is to generally guide practitioners and the market regarding these challenges with independent studies and explanations of relevant phenomena. 
It is interesting to observe that this theme was sufficiently relevant to birth a theory or interpretation where every company must account for changes in the market proposed by social, technological, environmental, economic and political (STEPS) drivers (Frank et al, 2014).

In this context, the insurance broker plays a central role as a consultant, demanding broader information-gathering, insight and collaboration.

According to Doherty and Muermann (2010), the insurance broker enjoys a privileged position in the relationship between a consumer and insurer and can solve the problem of asymmetric information limiting both. This information advantage is the key differentiator.

Accenture (an advising company) has stated about practitioners that, "their skills and experience will still be critical for many consumers seeking independent advice" (Mulhall et al., 2016).

The client is a crucial figure in the broker-client relationship and the success of the broker's business is based on a good and lasting relationship with clients (Beloucif \& Donaldson, 2004).

Experience in the insurance market and proximity to the client allow the insurance broker to develop specific know-how in the risk management field (not only in risk transfer which is usually their primary service).

\section{Materials and Method:}

The research was developed using quasi-quantitative methods, particularly:

1- A content analysis of the data presented on the institutional website (Winsvold, 2017; Youngblood \& Mackiewicz, 2012; Capriotti \& Moreno, 2007; Cappel \& Huan, 2007) to observe how many municipalities have an insurance broker as a partner; and

2- A threshold analysis with a dispersion diagram about the municipalities' dimensions, observing where the brokers are.

Furthermore, the database content was analysed for a binary response (Yes or No) about commitment to/entrustment of an insurance broker's services.

Subsequently, a quantitative analysis was performed on municipalities' size and population using a 'Yes' or 'No' response through a simple dispersion graphic and threshold analysis. The sample chosen was the relationship between degrees of transparency obligations in different regions.

Indeed, every public administration, in compliance with the Legislative Decree 33/2013 provides a section 'Transparency Administration' on its institutional website where the public can access a series of quantitative and qualitative information. 
Table 2 ranks the regions that fulfil this transparency obligation (or, even better, that have implemented in the institutional website the section 'Transparency Administration').

The project, called the Bussola della Trasparenza - MagellanoPA of the Italian Minister for Simplification and for Public Administration, has a wealth of easily accessible information about the public administration.

The Emilia-Romagna region, as shown in Table 2, is ranked 6th, which is just 4 percentage points different from the first region (Sardegna). 978 of the 1,172 public administrations have the section 'Transparency Administration' on their institutional website.

Although the presence of this 'transparency section' on the website does not imply the presence of the information, the choice of the sample was oriented towards the region Emilia-Romagna for primary observation.

The dataset was integrated with a link to the municipality's institutional website and information about relationships to insurance brokers. A random search within the website was used to obtain this data with keywords like 'broker', 'insurance broker' (brokeraggio assicurativo), in the function 'search' (if available), in the sections 'call for tender and contracts' and 'official notice board'.

The data were collected in April 2018, and the website's static information guarantees the reliability of the analysis (Krippendorff, 2004). Indeed, the response 'Yes' or 'No' signifies that the municipality analysed is or was related to an insurance broker or simply published this notice.

Data from the Italian Minister for Simplification and for Public Administration - May 2018

\begin{tabular}{llll}
\hline Position & Region & Percentage & Number PA/Total PA \\
\hline 1 & Sardegna & $87 \%$ & $671 / 767$ \\
2 & Lombardia & $86 \%$ & $2.610 / 3.022$ \\
3 & Piemonte & $86 \%$ & $1.826 / 2.120$ \\
4 & Valle D'Aosta & $85 \%$ & $128 / 150$ \\
5 & Friuli-Venezia Giulia & $84 \%$ & $439 / 520$ \\
6 & Emilia-Romagna & $83 \%$ & $978 / 1.172$ \\
7 & Veneto & $83 \%$ & $1.239 / 1.490$ \\
8 & Basilicata & $81 \%$ & $260 / 319$ \\
9 & Marche & $81 \%$ & $514 / 629$ \\
10 & $\quad$ Calabria & $80 \%$ & $660 / 824$ \\
11 & Liguria & $80 \%$ & $432 / 538$ \\
12 & Molise & $80 \%$ & $199 / 246$ \\
13 & Puglia & $79 \%$ & $844 / 1.056$ \\
14 & Toscana & $79 \%$ & $801 / 1.002$ \\
15 & Umbria & $79 \%$ & $231 / 292$ \\
16 & Campania & $77 \%$ & $1.219 / 1.576$ \\
17 & Sicilia & $77 \%$ & $1.182 / 1.517$ \\
18 & Abruzzo & $76 \%$ & $464 / 603$ \\
19 & Lazio & $73 \%$ & $1.058 / 1.432$ \\
20 & Trentino-Alto Adige & $71 \%$ & $566 / 790$ \\
\hline
\end{tabular}

Source: Our elaboration 


\section{Results}

The first outcome of the content analysis is shown in Table 3 which differentiates between municipalities that have an insurance broker as a partner and which do not or not published this notice.

$89 \%$ of the municipalities published on its website have a relationship with an insurance broker and only the $11 \%$ do not declare having this kind of relationship.

However, the municipalities that do not declare this relationship could have done an entrustment and simply not published on his website. Indeed, the Italian regulation on procurement permits the municipalities to not publish the information related to entrustment under a threshold (a little value) (Comba, 2019).

Table 3: Content Analysis Results on the Emilia-Romagna Municipalities

\begin{tabular}{cccc}
\hline $\begin{array}{c}\text { Qualitative } \\
\text { information } \\
\text { published }\end{array}$ & $\begin{array}{c}\text { Content Analysis } \\
\text { binary response }\end{array}$ & $\begin{array}{c}\text { Number of } \\
\text { Municipalities }\end{array}$ & $\begin{array}{c}\text { Percentage } \\
\%\end{array}$ \\
\hline $\begin{array}{c}\text { Insurance broker as a } \\
\text { partner }\end{array}$ & Yes & 296 & $89 \%$ \\
No information & No & 35 & $11 \%$ \\
& Total & 331 & $100 \%$ \\
\hline
\end{tabular}

Source: Our elaboration

Table 4 illustrates another result that ranks the first and the last municipality by size.

Table 4: Largest and smallest municipality

\begin{tabular}{cccccc}
\hline $\begin{array}{c}\text { Position: } \\
\mathbf{k m}^{2} / \text { /inab. }\end{array}$ & Municipality & $\begin{array}{c}\text { Surface } \\
(\mathbf{I n} \\
\left.\mathbf{k m}^{2}\right)\end{array}$ & Inhabitants & Institutional Web-site & $\begin{array}{c}\text { Binary } \\
\text { Response }\end{array}$ \\
\hline 1 & Bologna & 140.86 & 388,367 & $\underline{\text { http://www.comune.bologna.it// }}$ & Yes \\
& Zerba & 24.13 & 78 & http://www.comunedizerba.it/ & No \\
\hline 331 & \multicolumn{5}{c}{ Source: Our elaboration }
\end{tabular}

Other considerations emerge from analysing the simple dispersion graphic in Appendix I. It represents a dispersion graph of the municipalities by size (measured in surface area and number of inhabitants) that have a broker as a partner. Almost these municipalities are small-medium with 1000-50.000 inhabitants and surface in 1-400 km2 and only 13 municipalities are bigger the 50.000 inhabitants.

Furthermore, the threshold analysis presented in Appendix illustrates that municipalities that do not have a relationship with an insurance broker are 
medium-small with a threshold in "8,000 inhabitants" and a maximum size of roughly $190 \mathrm{~km}^{2}$.

\section{Discussion}

The analysis merges how an insurance broker is a partner in the municipalities of the Emilia-Romagna.

Although with the statistical limits of the observation, this result $-89 \%$ of declaration or notice published - demonstrates how this professional represents a resource for the municipalities.

The considerations discussed in the literature background suggest that risk management is a practice embedded in the public sector (Hinna et al., 2018). This first observation about the municipalities of the Emilia-Romagna show a possible way the insurance broker supports a municipality in its risk management system.

Academicians and practitioners explain how often the support of an insurance broker is on the management of the operational risks (Gjerdrum \& Peter, 2011; Cruz et al., 2015).

Moreover, the literature analysis showed that the internal control system in municipalities lacks operational risk management practices. These depend on proper management from public managers or officers (Hatvanti et al, 2015; Peta, 2016).

Finally, the thresholds analysis shows that almost all municipalities that published a notice of an entrustment with an insurance broker are smallmedium (1.000-50.000 inhabitants) and the 11\% that did not publish this notice are small municipalities (under the 8.000 inhabitants). This data might explain how almost all the municipalities have constructed a formalised risk management system and utilised a consultant to implement it.

\section{Conclusion}

The results of the content and threshold analyses allow for certain considerations. Responding to the first research question in the context of the literature review, it is possible to affirm that there is a legislative dearth of operational risk management actions in the municipalities' internal control system.

Indeed, although international guidelines exist to address organisational strategies, evaluating and implementing them is left to the 'sensibility' of the individual municipality.

Although the analysis was conducted on a sample limited to the Emilia-Romagna municipalities, it shows that almost all municipalities have a relationship with an insurance broker which hints at two hypotheses:

An insurance broker meets the need for operational risk management activities and transfers risk as necessary with an insurance contract. 
The municipality conducts risk management activities independently or assisted by the insurance broker, using him or her as a distribution channel to make a contract to transfer the risks.

Other considerations arise from the second research question: Could the insurance broker have a role in the public control system?

Surely, the insurance broker has developed know-how in risk management practices and offers not only mediation but also consultation services (Maas, 2006; Doherty \& Muermann, 2010).

This result highlights how insurance brokerages may develop innovative consultant services based on proximity to the client, providing an information advantage that primarily differentiates them from other operators in the sector.

Moreover, the evidence in this sample shows that municipalities have identified members from this profession as risk consultants or intermediaries, confirming brokers' strategic role in the risk management strategies adopted by public administration.

It is also interesting to observe that since 2009, the Italian Association of Insurance and Reinsurance Brokers (AIBA), aiming to create awareness about this partnership for public organisations, published a Guide to the utilized of the insurance broker in public administration. They published another guideline titled "The insurance broker in the public administration sector: Competence and independence at the service of citizens in 2018".

Management control logic has been introduced in public administration by new public management influences. Risk logic has been implemented to achieve objectives and manage operational risks and the lack of specific norms in the Italian legislative framework. Thus, it is necessary to address this lack and integrate management control systems and risk management activities (Hinna et al., 2018; Rana et al., 2019).

This analysis has a limited sample from a statistical perspective. However, it represents pioneering work and tries to understand risk management activities in the municipalities and the involvement of insurance brokers in the control system.

Future research will analyse more significant samples using other research methods like survey and interviews to understand the municipalities' processes and risk management perspective.

\section{References:}

1. Arnaboldi, M., Lapsley, I., \& Steccolini, I. (2015). Performance management in the public sector: The ultimate challenge. Financial Accountability \& Management, 31(1), $1-22$.

2. Banham, R. (2004). Enterprising views of risk management. Journal of Accountancy, 197(6), 65. 
3. Barton, T. L., Shenkir, W. G., Walker, P. L. (2002). Making enterprise risk management pay off: How leading companies implement risk management. Financial Times/Prentice Hall PTR. Upper Saddle River, NJ.

4. Beloucif, A., \& Donaldson, B. (2004). Insurance broker-client relationships: An assessment of quality and duration. Journal of Financial Services Marketing, 8(4), 327-342, Henry Stewart Publications.

5. Beloucif, A., Donaldson, B., Waddell, M. (2006). A systems view of relationship dissolution. Journal of Financial Services Marketing, 11(1), 30-48.

6. Bracci, E., Maran, L., \& Inglis, R. (2017). Examining the process of performance measurement system design and implementation in two Italian public service organisations. Financial Accountability \& Management, 33(4), 406-421.

7. Capaldo, G., Costantino, N., Pellegrino, R., \& Rippa, P. (2018). The role of risk in improving goal setting in performance management practices within public sector: An explorative research in courts offices in Italy. International Journal of Public Administration, 41(12), 986997.

8. Cardon, M. S., \& Stevens, C. E. (2004). Managing human resources in small organizations: What do we know? Human resource management review, 14(3), 295-323.

9. CINEAS. (2018). VI Edition observatory on the spread of risk management in Italian medium-sized companies. https://www.cineas.it/category/osservatorio-risk-management/ Consulted at March 2019

10. Colquitt, L. L., Hoyt, R. E., \& Lee, R. B. (1999). Integrated risk management and the role of the risk manager. Risk Management and Insurance Review, 2(3), 43-61.

11. Coso, I. I. (2004). Enterprise risk management. Integrated Framework.

12. Comba, M. E. (2019). Disclosure of public procurement documents in Italy: a major effort in the fight against corruption, but still to be completed. In Transparency in EU Procurements. Edward Elgar Publishing.

13. Cruz, M. G., Peters, G. W., \& Shevchenko, P. V. (2015). Fundamental aspects of operational risk and insurance analytics: A handbook of operational risk. John Wiley \& Sons.

14. Cummins, J. D., \& Doherty, N. A. (2006). The economics of insurance intermediaries. Journal of Risk and Insurance, 73(3), 359-396. 
15. Denhardt, R. B., \& Denhardt, J. V. (2000). The New Public Service: Serving Rather Than Steering. Public Administration Review,60(6), 549-559.

16. Doherty, N. A. (1997). Innovations in managing catastrophe risk. Journal of risk and insurance, 64(4), 713-718.

17. Doherty, N. A., \& Muermann, A. (2010). On the role of insurance brokers in resolving the known, the unknown, and the unknowable. The Known, the Unknown, and the Unknowable in Financial Risk Management: Measurement and Theory Advancing Practice, 194.

18. European Commission, (2006), Welcome to the world of PIFC, Public Internal Financial Control.

19. Eckardt, M., \& Räthke-Döppner, S. (2010). The quality of insurance intermediary services - empirical evidence for Germany. Journal of Risk and Insurance, 77(3), 667-701.

20. Frank P., Caceres K., Calandro J., Wolovnick E., (2014). Broking 2020: Leading from the front in a new era of risk. www.pwc.com/insurance. Consulted at March 2019

21. Focht, U., Richter, A., \& Schiller, J. (2013). Intermediation and (Mis) Matching in Insurance Markets-Who Should Pay the Insurance Broker?. Journal of Risk and Insurance, 80(2), 329-350.

22. Guthrie, J., Humphrey, C., Jones, L. R., \& Olson, O. (Eds.). (2005). International public financial management reform: progress, contradictions, and challenges. IAP.

23. Gordon, L. A., Loeb, M. P., \& Tseng, C. Y. (2009). Enterprise risk management and firm performance: A contingency perspective. Journal of Accounting and Public Policy, 28(4), 301-327.

24. Gjerdrum, D., \& Peter, M. (2011). The new international standard on the practice of risk management-A comparison of ISO 31000: 2009 and the COSO ERM framework. Risk management, 31(21), 8-12.

25. Hatvani, E. N. C. (2015). Risk analysis and risk management in the public sector and in public auditing. Public Finance Quarterly, 1(7).

26. Hinna, A., Scarozza, D., \& Rotundi, F. (2018). Implementing risk management in the Italian public sector: Hybridization between old and new practices. International Journal of Public Administration, 41(2), 110-128.

27. Hood, C. (1995). The 'New Public Management' in the 1980s: Variations on a theme. Accounting, organisations and society, 20(2-3), 93-109.

28. Hood, C. (2000). The art of the state: Culture, rhetoric and public management. Oxford: Claredon. 
29. Hood, C. (2005). Public Management: The Word, the Movement, the Science. In L. E. Ferlie, L. E. Lynn and C. Pollitt (Eds.), The Oxford Handbook of Public Management. Oxford: Oxford University Press.

30. Hoyt, R. E., \& Liebenberg, A. P. (2011). The value of enterprise risk management. Journal of Risk and Insurance, 78(4), 795-822.

31. Hornai, G. (2001). Kockázat és kockázatkezelés. (Risk and Risk Management). (MVM Hungarian Electricity Company Disclosures. 2001/04).

32. INTOSAI (2004). INTOSAI GOV 9130 - Guidelines for Internal Control Standards for the Public Sector - Further Information on Entity Risk Management. Retrieved from www.issai.org. Consulted at March 2019

33. Kaplan, S., \& Garrick, B. J. (1981). On the quantitative definition of risk. Risk analysis, 1(1), 11-27.

34. Kapuscinska, K. Z., \& Matejun, M. (2014) Risk management in public sector organizations: A case study. International Journal of Business and Management, 3(3), 129-143.

35. Khan H. A. (2018) Governance, Public administration, and the challenges of globalization. In: Globalization and the Challenges of Public Administration. Palgrave Macmillan, Cham

36. Keban, Y. T. (2017). Risk management: a neglected vital instrument in public administration in Indonesia. Management Research and Practice, 9(4), 5-21.

37. Kickert, W. J. (2001). Public management of hybrid organisations: governance of quasi-autonomous executive agencies. International Public Management Journal, 4(2), 135-150.

38. Lam, J., (2003). Enterprise risk management: From incentives to controls. John Wiley \& Sons, Inc., Hoboken, New Jersey.

39. Larbi, G. (1999). The new public management approach and crisis states. United Nations Research Institute Social Development (Vol. 112). Discussion Paper

40. Maas, P. (2006). How insurance brokers create value-a functional approach. Risk Management and Insurance Review, 13(1), 1-20.

41. Maran, L., Bracci, E., \& Inglis, R. (2018). Performance management systems' stability: Unfolding the human factor-A case from the Italian public sector. The British Accounting Review, 50(3), 324-339.

42. Mulhall, J., Chauhan, A., Lindsey, C., \& Lyman, M. (2016). The broker of the future. Accenture.

43. Mussari, R. (Ed.). (2001). Operational manual for management control. Rubbettino Editore. 
44. Nilsen, A. S., \& Olsen, O. E. (2005). Different strategies-Equal practice? Risk assessment and management in municipalities. Risk Management, 7(2), 37-47.

45. OECD. (1996). Management control in modern government administration: Some comparative practices. SIGMA Papers, No. 4. Paris, FR: OECD Publishing.

46. Ongaro, E., \& Valotti, G. (2008). Public management reform in Italy: Explaining the implementation gap. International Journal of Public Sector Management, 21(2), 174-204.

47. Padovani, E., Yetano, A., \& Orelli, R. L. (2010). Municipal performance measurement and management in practice: which factors matter? Public Administration Quarterly, 591-635.

48. Peleckiene, V., Peleckis, K., Dudzeviciute, G., \& Lapinskiene, G. (2017). Changes of insurance intermediaries regulation in the EU countries. In Economic Science for Rural Development Conference Proceedings (No. 46).

49. Petak, W. J. (1985). Emergency management: A challenge for public administration. Public Administration Review, 45, 3-7.

50. Peta, Anna. (February 25, 2016). I controlli interni della pubblica amministrazione: criticità e prospettive evolutive (Internal controls in the public administration: current problems and future challenges) Bank of Italy Occasional Paper No. 312.

51. Rana, T., Wickramasinghe, D., \& Bracci, E. (2019). New development: Integrating risk management in management control systems-lessons for public sector managers. Public Money \& Management, 39(2), 148-151

52. Rajola F., Frigerio C., Gatelli P., Mastrantoni C., Pippione G., (2016), Agent Channel: Agency models, roles and skills for insurance consultancy. Research Report, CeTIF.

53. Raczkowski, Konrad. (2017). Risk management in public administration. Cham, Switzerland: Palgrave Macmillan.

54. Reginato, E., Nonnis, C., \& Pavan, A. (2002). Modern public internal control systems and accountability in health care organisations. Economia Aziendale Online, 2(4), 381-396.

55. Robinson, M. (2015). From old public administration to the new public service: Implications for public sector reform in developing countries. UNDP Global Centre for Public Service Excellence.

56. Riso, V., \& Castellini, M. (2019). Poor integration between operational risk management activities and internal control system in the municipalities: an analysis of the Italian legislative framework. Economia Aziendale Online, 10(1), 149-158. 
57. Rosenthal, N. L. (1995). Insurance broker as risk consultant. Risk Management, 42(6), 33.

58. Ruffini, R. (2004). Fondamenti di economia delle aziende e delle amministrazioni pubbliche. Roma, Italy: De Agostini professionale.

59. Ruffini, R. (2010). L'evoluzione dei sistemi di controllo nella pubblica amministrazione. Milan, Italy: Franco Angeli.

60. Sandelowski, M. (2000). Combining qualitative and quantitative sampling, data collection, and analysis techniques in mixed-method studies. Research in Nursing \& Health, 23(3), 246-255.

61. Schmit, J. T., \& Roth, K. (1990). Cost effectiveness of risk management practices. Journal of Risk and Insurance, 455-470.

62. Verbeeten, F. H., \& Speklé, R. F. (2015). Management control, resultsoriented culture and public sector performance: Empirical evidence on new public management. Organization Studies, 36(7), 953-978.

63. Sharma N., Patterson P.G., (1999), The impact of communication effectiveness and service quality on relationship commitment in consumer, professional services. Journal of Services Marketing, 13(2), $151-170$

64. Soin, K., \& Collier, P. (2013). Risk and risk management in management accounting and control. 


\section{Appendix:}

Appendix I: Dispersion diagram of municipalities with insurance broker or that declare it on institutional web-site

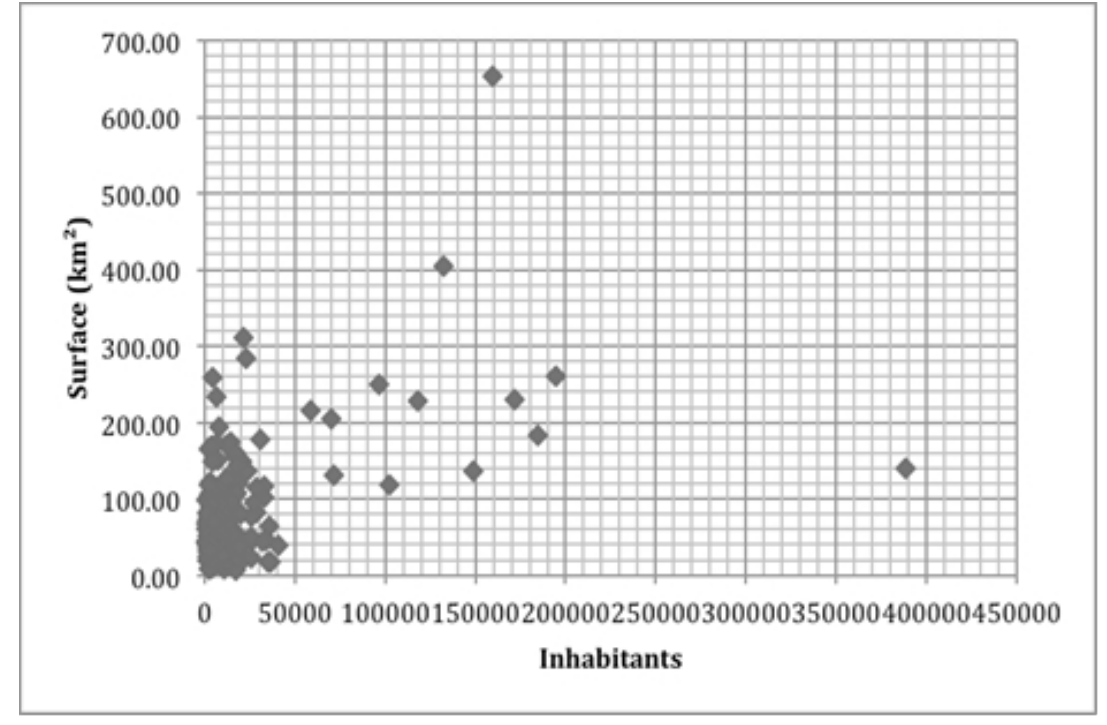

Appendix II: Dispersion diagram of municipalities without insurance broker or that not declare it on institutional web-site

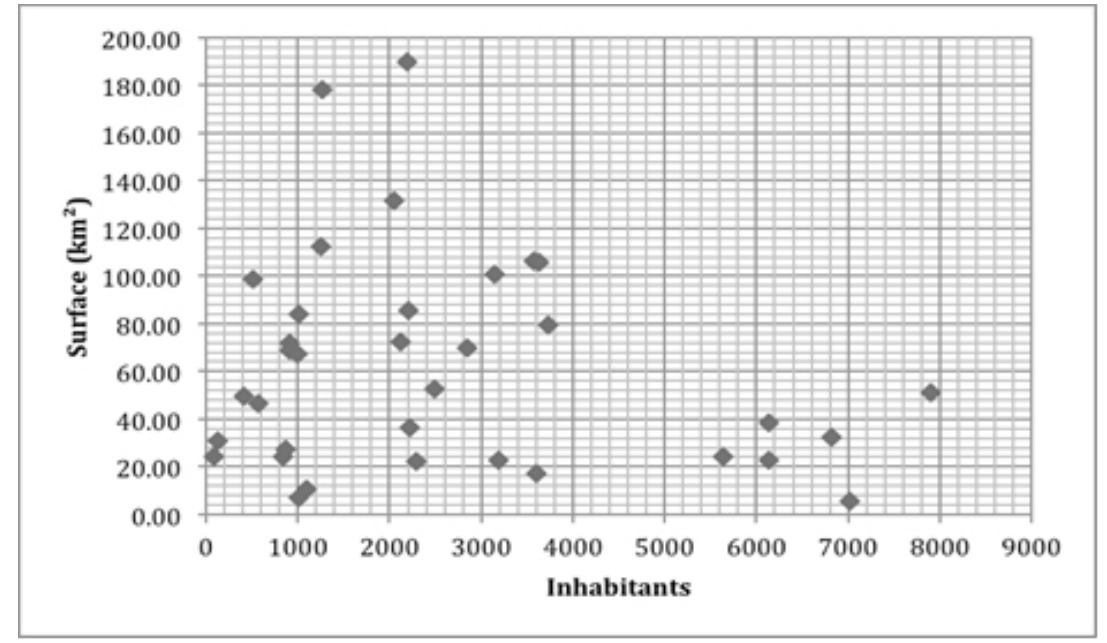

